\title{
RELEVANSI PENGUNGKAPAN TRANSAKSI PIHAK BERELASI. APAKAH PASAR MEMBERIKAN RESPON?
}

\author{
Dian Yuni Anggraeni \\ Universitas Andalas \\ Email : dianyuni12@gmail.com
}

\begin{abstract}
Abstrak
Information is the result of a number of data processing. The relevance of information related to the usefulness of the information to support decision-making. One of the information in the financial statements which are popular is the information about transactions with related parties. This information is important because it can be used as a tool for management to report its best performance, which in fact is not (earnings management - opportunistic).

This study sought to provide empirical evidence about the relevance of the extent of disclosure of related party transactions. Relevance proxies at the company's stock price. The results indicate that the related party transaction information which is proxied by the extent of disclosure of compensation of key management and reported presence of sales and purchases with related parties is relevant to the market
\end{abstract}

Keywords: disclosure, related parties transaction, relevance.

\section{Pendahuluan}

Ketidakcukupan informasi yang diungkapkan dalam laporan keuangan banyak mengakibatkan terjadinya skandal yang merugikan beberapa pihak. Berdasarkan karakteristik kualitatif kerangka konseptual IFRS (International Financial Reporting Standards), pentingnya informasi bukan hanya dilihat dari segi komposisinya, namun juga tingkat relevansi dan keakuratan serta keandalan penyajiannya. Kerangka Dasar Penyusunan dan Penyajian Laporan Keuangan (KDPPLK) menyatakan bahwa tujuan laporan keuangan ialah untuk memberikan informasi berkenaan dengan posisi keuangan, kinerja, serta perubahan posisi keuangan suatu entitas.

Relevansi informasi akuntansi berkaitan dengan bagaimana reaksi pasar atas informasi yang diumumkan (Puspitaningtyas, 2012). Salah satu upaya untuk menyajikan informasi yang relevan, pada tahun 2010 Ikatan Akuntan Indonesia (IAI) menerbitkan PSAK No. 7 (Revisi 2010) tentang Pengungkapan Pihak-pihak Berelasi. PSAK ini mengadopsi IAS 24 tentang Related Party Disclosure. PSAK ini mengatur mengenai pengungkapan hubungan, transaksi dan saldo pihakpihak berelasi, termasuk komitmen, dalam laporan keuangan konsolidasian dan laporan keuangan sendiri entitas induk. Transaksi dengan pihak berelasi penting untuk diatur karena keberadaan pihak berelasi dan komitmen pihak tersebut akan mempengaruhi transaksi dan saldo suatu entitas hingga pada akhirnya juga akan berpengaruh terhadap perubahan posisi keuangan serta laba rugi entitas.
Penelitian ini fokus pada bagaimana reaksi pasar terhadap informasi transaksi pihak berelasi yang diungkapkan oleh manajemendalam laporan keuangan.Belum banyak penelitian di Indonesia mengenai relevansi pengungkapan transaksi pihak berelasi.Beberapa diantaranya ialah menguji keefektifan tata kelola perusahaan serta manajemen laba terhadap transaksi pihak berelasi.Untuk mengisi celah penelitian tersebut, maka penelitian ini berusaha untuk menjawab apakah terdapat nilai yang relevan atas diungkapkannya informasi mengenai pihak berelasi pada pasar.

Dalam penelitian ini, respon pasar diproksikan dengan harga saham. Diasumsikan bahwa jika standar pengungkapan informasi transaksi pihak berelasi (PSAK No. 7) adalah efektif, maka para investor akan bereaksi dengan direpresentasikan dari nilai harga saham perusahaan (Ge et al., 2010).

Pengungkapan informasi kompensasi manajemen kunci dapat mempengaruhi pengambilan keputusan oleh investor karena Conyon dan He (2011) mengklaim bahwa performa perusahaan dapat direpresentasikan dengan luasnya pengungkapan kompensasi manajemen kunci perusahaan.Potensi hadirnya manajemen laba yang bersifat opportunis, dapat ditimbulkan karena adanya pembayaran kompensasi kepada manajemen kunci sebagai salah satu pihak berelasi suatu entitas.Sikap ini diakibatkan karena adanya konflik keagenan, dimana manjemen dapat menggunakan otoritasnya untuk menyajikan informasi yang menunjukkan keefektifan 
kinerja mereka.Sehingga, imbalan yang mereka dapatkan adalah maksimal (Jensen dan Meckling, 1976).

Ge et al. (2010) menemukan adanya penurunan relevansi nilai laba yang dilaporkan entitas karena adanya transaksi penjualan dan pembelian dengan pihak berelasi.Distorsi diskresi manajemen atas transaksi dengan pihak berelasi dapat dijadikan alat untuk melaporkan kinerja manajemen yang tidak sesuai dengan keadaan ekonomi entitas yang sebenarnya.Mc Vay (2006) mengklaim bahwa komponen-komponen pembentuk laba merupakan hal penting untuk mendeteksi entitas dalam praktik manajemen laba. Hal ini tentu saja akan mempengaruhi persepsi investor dalam keputusan investasinya, baik keputusan untuk membeli, menjual, atau mempertahankan kepemilikan sahamnya.

Hasil penelitian ini dapat menjadi masukan bagi perusahaan agar memperluas pengungkapan transaksi dengan pihak berelasi untuk mengurangui biaya modal mereka sehingga mendapat perhatian bagi para calon investor.

Penelitian ini berkonsentrasi pada kandungan informasi laba serta informasi laporan keuangan lainnya.Penelitian ini mengukur kandungan informasi laba dengan melihat apakah laba yang dilaporkan lebih tinggi dari ekspektasi good news atau lebih rendah dari ekspektasi pasar bad news.

\section{Pembahasan}

PSAK No. 7 direvisi pada tahun 2010 dan implementasi standar ini efektif untuk tahun buku yang dimulai pada atau setelah 1 Januari 2011.Ruang lingkup dari PSAK No. 7 meliputi identifikasi hubungan serta transaksi pihak berelasi, identifikasi saldo dan komitmen antar perusahaan dengan pihak berelasi, dan pengungkapannya.

Informasi mengenai kompensasi manajemen kunci wajib dilaporkan oleh perusahaan. Hal ini karena keberadaannya akan mempengaruhi keputusan operasi dan resiko entitas. Namun, dalam standar tidak ditentukan secara baku informasi mengenai kompensasi ini, baik dalam hal pengungkapan siapa saja manajemen kunci tersebut dan kategori kompensasi yang didapat oleh para manajemen kunci. Oleh karena itu, dalam laporan keuangan setiap perusahaan masih ditemukan beragam penyajian informasi kompensasi manajemen kunci sebagai agen pemegang saham dalam perusahaan (Akmyga dan Farahmita, 2013).

Permasalahan keagenan berhubungan erat dengan informasi.Oleh karena itu, dalam meminimalisir permasalahan ini dilakukan suatu mekanisme pengungkapan dan pelaporan.Healy dan Palepu (2001) mengatakan bahwa agency problem terjadi ketika manajer dan prinsipal memiliki dua kepentingan yang berbeda.Terdapat intervensi kepentingan manajemen dalam mengungkapkan informasi pada laporan keuangan. Hal tersebut mengakibatkan adanya benturan kepentingan sehingga timbul asymmetric informationdalam pengungkapan hasil evaluasi kerja antara sang pemilik modal dan pengelolanya. Jensen dan Meckling (1976) mengatakan bahwa asymmetric information adalah ketidak seimbangan informasi yang disebabkan karena adanya distribusi informasi yang tidak merata antara prinsipal dan agen, sehingga menimbulkan permasalahan yaitu adanya kesulitan pengawasan dan pengendalian terhadap tindakan dan aktivitas agen.

Sun (2014) mengatakan bahwa kompensasi eksekutif merupakan salah satu motif dilakukannya manajemen laba.Kemudian, Kohlbeck dan Mayhew (2010) berasumsi bahwa terdapat sikap opportunis manajemen dalam transaksi antar pihak berelasi yang mengakibatkan rendahnya penilaian pasar.Berdasarkan pemaparan tersebut, hipotesis pertama dalam penelitian ini adalah:

H1: Pengungkapan informasi kompensasi manajemen kunci berpengaruh positif dengan harga saham.

Ge et al. (2010) menemukan adanya penurunan relevansi nilai laba yang dilaporkan entitas karena adanya transaksi penjualan dan pembelian dengan pihak berelasi.Penyalahgunaan diskresi manajemen atas transaksi dengan pihak berelasi dapat dijadikan alat untuk melaporkan kinerja manajemen yang tidak sesuai dengan keadaan ekonomi entitas yang sebenarnya.

Mc Vay (2006) mengklaim bahwa komponen-komponen pembentuk laba merupakan hal penting untuk mendeteksi entitas dalam praktik manajemen laba. Hal ini akan mempengaruhi persepsi investor dalam keputusan investasinya, baik keputusan untuk membeli, menjual, atau mempertahankan kepemilikan sahamnya.

Berdasarkan penjabaran landasan teori dan penelitian sebelumnya diatas, hipotesis kedua dan ketiga dalam penelitian ini adalah:

H2: Transaksi penjualan dengan pihak berelasi akan berpengaruh negatif terhadap harga saham.

H3: Transaksi pembelian dengan pihak berelasi akan berpengaruh negatif terhadap harga saham.

Data dalam penelitian ini ialah seluruh laporan keuangan perusahaan manufaktur yang terdaftar di BEI pada periode 2012-2013.Data laporan keuangan diunduh dari website resmi BEI (www.idx.co.id), pemilihan sampel dilakukan dengan teknik purposive sampling, yaitu populasi yang dijadikan sampel adalah yang memenuhi kriteria tertentu.

Untuk menguji ketiga hipotesis, digunakan uji regresi data panel.Pengujian dilakukan dengan menggunakan software ekonometrik EViews 6.Model penelitian adalah sebagai berikut ini: 


$$
\begin{aligned}
\text { PRICE }_{i t}=\beta_{0}+ & \beta_{1} \text { MCDISC }_{i t} \\
& +\beta_{2} \text { SALESRPT }_{i t} \\
& +\beta_{3} \text { PURCHRPT }_{i t} \\
& +\beta_{4} \text { EPS }_{i t}+\beta_{5} \mathrm{BV}_{i t} \\
& +\varepsilon_{i t}
\end{aligned}
$$

PRICEit merupakan proksi untuk mengukur relevansi informasi yang diungkapkan dalam laporan keuangan (Cheng et al., 1996). Variabel dependen ini diukur dengan harga saham per lembar saham perusahaan pada 31 Maret $\mathrm{t}+1$, atau tiga bulansetelah tahun buku yang berakhir pada 31 Desember periode tPenentuan tanggal tersebut ditujukan untukmelihat bagaimana reaksi pasar setelah diterbitkannyalaporan keuangan perusahaan kepada publik (Ge et al., 2010).

Terdapat tiga variabel independen utama dalam penelitian ini, yaitu MCDISC $_{i t}$, SALESRPT $_{i t}$, dan PURCHRPT $_{\text {it. }}$ Variabel MCDISC it $_{\text {merupakan proksi dari }}$ luasnya pengungkapan kompensasi manajemen kunci dalam laporan keuangan perusahaan i pada periode t.Parameter untuk variabel ini mengadopsi penelitian yang dilakukan oleh Akmyga dan Farahmita (2013).

SALESRPT $_{\text {it }}$ merupakan variabel dummy, bernilai 1 jika laba yang dilaporkan mengandung transaksi penjualan dengan pihak berelasi, dan 0 lainnya. Kemudian, PURCHRPT $_{\text {it }}$ merupakan variabel dummy, bernilai 1 jika laba yang dilaporkan mengandung transaksi pembelian dengan pihak berelasi, 0 lainnya (Ge et al., 2010).

Dua variabel kontrol untuk menguji relevansi informasi akuntansi dalam laporan keuangan penelitian ini ialah $\mathrm{EPS}_{\mathrm{it}} \mathrm{dan} \mathrm{BV}_{\mathrm{it}} \cdot \mathrm{EPS}_{\mathrm{it}}$ merupakan laba per lembar saham perusahaan i pada periode $t$, sedangkan $\mathrm{BV}_{\mathrm{it}}$ ialah nilai buku ekuitas per lembar saham perusahaan i pada

\begin{tabular}{|c|c|c|c|c|c|}
\hline Variabel & Mean & Median & $\begin{array}{l}\text { Maksimu } \\
\mathrm{m}\end{array}$ & $\begin{array}{l}\text { Minimu } \\
\mathrm{m}\end{array}$ & $\begin{array}{l}\text { Std. } \\
\text { Dev }\end{array}$ \\
\hline PRICE & $\begin{array}{l}20031.8 \\
3\end{array}$ & $\begin{array}{l}710.000 \\
0\end{array}$ & 1100000 & $\begin{array}{l}50.0000 \\
0\end{array}$ & $\begin{array}{l}110179 . \\
1\end{array}$ \\
\hline $\begin{array}{l}\text { MCDIS } \\
\mathrm{C}\end{array}$ & $\begin{array}{l}0.30588 \\
2\end{array}$ & $\begin{array}{l}0.10000 \\
0\end{array}$ & 1.000000 & $\begin{array}{l}0.00000 \\
0\end{array}$ & $\begin{array}{l}0.35479 \\
1\end{array}$ \\
\hline $\begin{array}{l}\text { SALESR } \\
\text { PT }\end{array}$ & $\begin{array}{l}0.85294 \\
1\end{array}$ & $\begin{array}{l}1.00000 \\
0\end{array}$ & 1.000000 & $\begin{array}{l}0.00000 \\
0\end{array}$ & $\begin{array}{l}0.35503 \\
6\end{array}$ \\
\hline $\begin{array}{l}\text { PURCH } \\
\text { RPT }\end{array}$ & $\begin{array}{l}0.81862 \\
7\end{array}$ & $\begin{array}{l}1.00000 \\
0\end{array}$ & 1.000000 & $\begin{array}{l}0.00000 \\
0\end{array}$ & $\begin{array}{l}0.38627 \\
4\end{array}$ \\
\hline EPS & $\begin{array}{l}1970.70 \\
3\end{array}$ & $\begin{array}{l}48.8750 \\
0\end{array}$ & 57000.00 & $\begin{array}{l}- \\
4999.00 \\
0\end{array}$ & $\begin{array}{l}8319.39 \\
9\end{array}$ \\
\hline BV & $\begin{array}{l}4047.57 \\
8\end{array}$ & $\begin{array}{l}579.740 \\
0\end{array}$ & 129007.3 & $\begin{array}{l}- \\
2718.70 \\
0\end{array}$ & $\begin{array}{l}13585.0 \\
8\end{array}$ \\
\hline
\end{tabular}
periode $\mathrm{t}$.

Hasil statistik deskriptif dari data penelitian ini disajikan dalam tabel 3 berikut ini:
Tabel 1.Statistik Deskriptif

Hasil uji Hausman dan uji Langrange Multiplier

\begin{tabular}{|c|c|c|c|}
\hline \multicolumn{4}{|c|}{$\begin{aligned} \text { PRICE }_{i t}=\beta_{0}+\beta_{1} \text { MCDISC }_{i t}+\beta_{2} \text { SALESRPT }_{i t} \\
+\beta_{3} \text { PURCHRPT }_{i t}+\beta_{4} \text { EPS }_{i t}+\beta_{5} \text { BV }_{i t} \\
+\varepsilon_{i t}\end{aligned}$} \\
\hline Variabel & Predict Sign & Koefisien & Prob \\
\hline $\mathbf{C}$ & & -2401.453 & 0.5814 \\
\hline MCDISC & + & $46554.45 * * *$ & 0.0000 \\
\hline SALESRPT & - & $-16900.72 * * *$ & 0.0000 \\
\hline PURCHRPT & - & $16361.08 * * *$ & 0.0000 \\
\hline EPS & + & $0.609816^{*}$ & 0.1755 \\
\hline BV & + & $1.979709 * * *$ & 0.0006 \\
\hline $\begin{array}{l}\text { R squared } \\
\text { Adj. R squared } \\
\text { F stat } \\
\text { Prob (F stat) } \\
\text { Durbin Watson } \\
\text { stat } \\
\text { N }\end{array}$ & $\begin{array}{l}0,403101 \\
0,388028 \\
26,74287 \\
0,000000 \\
1,831748 \\
204\end{array}$ & & \\
\hline
\end{tabular}
menunjukkan bahwa model terbaik dalam penelitian ini ialah Random Effect Model (REM). Hasilnya ialah sebagai berikut:

Tabel 2. Hasil Regresi

Berdasarkan hasil pengujian regresi tersebut, secara parsial menunjukkan bahwa Variabel MCDISC $_{\mathrm{it}}$ menunjukkan adanya hubungan positif dan signifikan $(\alpha=1 \%)$. Hasilnya menunjukkan bahwa setiap kenaikan luas pengungkapan kompensasi manajemen kunci sebesar 1 satuan akan meningkatkan harga saham perusahaan sebesar Rp 44.152,99 (46.554,45-2.401,45). 
Oleh karena itu, dapat disimpulkan bahwa hipotesis pertama diterima, terdapat nilai relevan dari diungkapkannya informasi kompensasi manajemen kunci perusahaan. Variabel SALESRPT it $_{\text {menunjukkan }}$ adanya hubungan negatif dan signifikan $(\alpha=1 \%)$. Hal ini berarti bahwa saat terjadinya penjualan dengan pihak berelasi, harga saham akan menurun sebanyak Rp 14.499,28 (16.900,72-2.401,45). Dapat disimpulkan bahwa, pengungkapan penjualan dengan pihak berelasi akan direspon negatif oleh investor. Hal ini mengindikasikan adanya nilai relevan dari pengungkapan penjualan dengan pihak berelasi, dan hipotesis kedua diterima.

Variabel $\mathrm{PURCH}_{\mathrm{it}}$ menunjukkan adanya hubungan positif dan signifikan $(\alpha=1 \%)$. Hal ini berarti bahwa saat terjadinya pembelian kepada pihak berelasi, harga saham akan cenderung naik sebanyak Rp 13.959,63 (16.361,08$2.401,45)$. Hasil ini bertolak belakang dengan prediksi hipotesis yang dibangun.Walau demikian, dengan melihat nilai signifikansi pada variabel ini dapat diakatkan bahwa informasi mengenai pembelian dengan pihak berelasi tetap dianggap relevan oleh para investor. Variabel EPS it $_{\text {it }}$ munjukkan adanya hubungan positif dan signifikan pada tingkat $\alpha$ sebesar 5\%, sedangkan variabel $\mathrm{BV}_{\text {it }}$ berada pada tingkat $\alpha$ sebesar $1 \%$. Hal ini menunjukkan bahwa kedua informasi tersebut adalah relevan bagi keputusan investasi para investor.

Secara simultan (uji-F), seluruh variabel menunjukkan pengaruh yang signifikan.Artinya, kelima variabel independen utama dan kontrol berpengaruh terhadap harga saham. Model dalam penelitian ini memiliki nilai adjusted R-square sebesar 0,388028 atau $38,8 \%$. Hasil tersebut mengindikasikan bahwa variasi variabel independen utama dan kontrol tersebut mampu menjelaskan variabel dependen dalam model penelitian ini sebesar $38,8 \%$, sisanya $61,2 \%$, dapat dijelaskan oleh variabel lain yang tidak termasuk kedalam model penelitian ini.

\section{Kesimpulan}

Penelitian ini berusaha untuk memperoleh bukti empiris berkenaan dengan apakah dalam pengungkapan informasi transaksi pihak berelasi mengandung nilai yang relevan bagi para investor perusahaan manufaktur yang tercatat di Bursa Efek Indonesia periode 20122013.Penelitian ini dilakukan setelah adanya revisi PSAK No. 7 pada tahun 2010.Hasil penelitian menunjukkan bahwa diungkapkannya informasi transaksi pihak berelasi memiliki pengaruh yang relevan.Hal ini dapat dilihat bahwa setelah diungkapkannya informasi tersebut, terdapat respon dari perubahan harga saham perusahaan.

Penelitian ini memiliki beberapa keterbatasan, pertama sampel yang digunakan hanya perusahaan manufaktur saja.Kemudian rentang waktu penelitian hanya dua tahun.Hal tersebut dapat mempengaruhi hasil generalisasi penelitian terhadap relevansi penerapan PSAK No. 7. Kemudian, jika dilihat dari nilai determinasi (R-square) dalam model masih rendah, oleh karena itu, penelitian selanjutnya dapat menambah variabel pengungkapan lain yang berkaitang dengan transaksi pihak berelasi, misalnya saja transaksi sewa. Kemudian penelitian selanjutnya juga dapat menggunakan persentase dari transaksi pihak berelasi terhadap reaksi pasar.

\section{Daftar Pustaka}

Akmyga, Stalsa Frani and Farahmita, Aria. (2013), "Pengaruh Struktur Corporate Governance terhadap Luas Pengungkapan Kompensasi Manajemen Kunci di Laporan Keuangan," Simposium Nasional Akuntansi XVI.

Ball, Brown. (1968), "An Empirical Evaluation of Accounting Income Number," Jurnal of Accounting Research, Autumn. 159-177.

Barth, Mary E., et al. (2001), "The Relevance of the Value Relevance Literature for Financial Accounting Standard Setting: Another Review," Journal of Accounting and Economics. Vol. 31.77-104.

Barth, Mary E. (2003), "Discussion of 'Compensation Policy and Discretionary Disclosure," Journal of Accounting and Economics.Vol. 34.311-318.

Bartov, Eli. (1993), "The Timing of Asset Sales and Earning Manipulation," The Accounting Review.Vol 68.No. 4.840-855.

Conyon, M. J., and He, L. (2001), "Executive Compensation and Corporate Governance in China," Journal of Corporate Governance.Vol.17.1158-1175.

Ge, Wenxia, et al. (2010), "Value Relevance of Disclosed Related Party Transactions," Advances in Accounting, Incorporating Advances in International Accounting. Vol. 26.134-141.

Gordon, E. A. and Henry, E. (2005), "Related Party Transaction and Earning Management," Working Paper: Rutgers University and University of Miami.

Healy, P. M. and Palepu, K. G. (2001), "Information Asymmetry, Corporate Disclosure, and the Capital Markets: A Review of the Empirical Disclosure Literature," Journal of Accounting and Economics. Vol. 31. No. 1-3. 405-440.

Ikatan Akuntan Indonesia, (2010), PSAK No. 7. Pengungkapan Pihak Berelasi. Jakarta.

Jensen, Michael C. dan Meckling, William H. (1976), "Theory of the Firm: Managerial Behavior, Agency Costs and Ownership Structure," Journal of Financial Economics. Vol. 3. No. 4. 305-360.

Kusuma, Hadri. (2006), "Dampak Manajemen Laba terhadap Relevansi Informasi Akuntansi: Bukti Empiris dari Indonesia," Jurnal Akuntansi dan Keuangan. Vol. 8.1-12. 
Kohlbeck, Mark and Mayhew, Brian W. (2010), "Valuation of Firm that Disclose Related Party Transactions," Journal of Accounting and Public Policy. Vol. 29.115-137.

McVay, S. E. (2006), "Earning Management Using Classification Shifting: An Examination of Core Earning and Special Items," The Accounting Review. Vol. 81.No. 3.501-531.

Puspitaningtyas, Zarah. (2012), "Relevansi Nilai Informasi Akuntansi dan Manfaatnya bagi Investor," Ekuitas: Jurnal Ekonomi dan Keuangan. Vol. 16.164-183.

Pozzoli, Matteo and Venuti, Marco. (2014), "Related Party Transactions and Financial Performance: Is There a Correlation? Empirical Evidence from Italian Listed Companies," Open Journal of Accounting. Vol 3.28-37.

Sun, Bo. (2014), "Executive Compensation and Earning Management under Moral Hazard," Journal of Economic Dynamics and Control.Vol 41.276290.

Utama, Sidharta, et al. (2010), "Related Party Transaction-Efficient or Abusive: Indonesia Evidence," Asia Pasific Journal of Accounting and Finance. Vol 1.77-102.

CHALANDAR, M. E., DARVISH, P. \& RAHMANI, A. M. A centralized cookie-based single sign-on in distributed systems. Information and Communications Technology, 2007. ICICT 2007. ITI 5th International Conference on, 16-18 Dec. 2007 2007. 163-165.

JIUN-HAU, L., SHIRLY, L., IVY, O., HOON-JAE, L. \& HYOTAEK, L. One-Time Knocking framework using SPA and IPsec. 2010 2nd International Conference on Education Technology and Computer, 22-24 June 2010 2010. V5-209-V5-213. 